\section{Viktig bok om sosialmedisin}

Mæland JG, Elstad JI, Næss $\emptyset$ et al, red. Sosial epidemiologi

Sosiale årsaker til sykdom og helsesvikt. 363 s, tab, ill. Oslo: Gyldendal Akademisk, 2009. Pris NOK 545

ISBN 978-82-05-39268-7

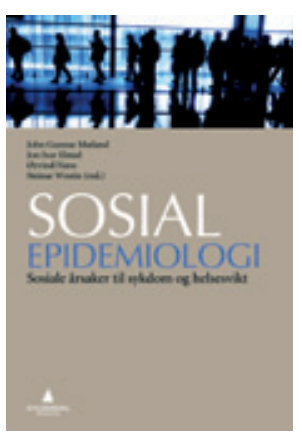

Dette er en omfattende lærebok i sosial epidemiologi med professor John Gunnar Mæland som primus motor. I redaksjonen har han fătt med seg sosiologen Jon Ivar Elstad og sosialmedisinerne Øyvind Erik Næss og Steinar Westin, og for øvrig 21 andre medforfattere.

Forfatterne vender seg mot alle som er engasjert i folkehelsearbeid, særlig studenter i helse- og sosialfag. De fire hovedbolkene omfatter: Sosiale helseulikheter i Norge, De sosiale, kulturelle og samfunnsmessige helsedeterminantene, Hvordan kan sosial ulikhet i helse forklares og til slutt Kunnskap og handling.

I vestlige land er det dokumentert betydelige sosiale ulikheter i befolkningens helsetilstand. I Storbritannia, med sine store, sosiale klasseforskjeller, finner man langt større dødelighet i de lavere enn i de høyere lagene. I Oslo er dødeligheten mye høyere i de indre, østlige bydelene enn i de vestlige strøkene av byen. En studie av Johan Mackenbach fra 1997 fant for øvrig at Sverige og Norge hadde, sammenliknet med andre europeiske land, de største relative ulikhetene.

Mange av dagens folkesykdommer henger åpenbart sammen med uheldige levevaner som er sosialt ulikt fordelt. Både tobakksrøyking og storspising er for eksempel i dag langt hyppigere i lavere enn i høyere sosiale lag av befolkningen. Et viktig spørsmål blir dermed: Hva former vår livsstil?

Odd Steffen Dalgard og Tom Sørensen viser i et kapittel hvordan mangelen på sosial støtte øker risikoen for psykiske lidelser og å dø av somatiske sykdommer, i første rekke hjerte- og karlidelser. Manglende sosial støtte er knyttet til ugunstig livsstil og eksponering for ulike belastninger, men også en tendens til å søke faglig hjelp sjeldnere enn vanlig.

I den tredje delen diskuterer man forskjellige forklaringer på de registrerte helseulikhetene. Jon Ivar Elstad og Øyvind Næss skriver innsiktsfullt om genetikk og sosiale helseulikheter og avviser med god grunn genetikken som hovedforklaring.

En forfattergruppe på et kvart hundre personer burde selvsagt garantere for at spisskompetansen på hele det sosialepidemiologiske feltet er dekket. Men kanskje blir likevel svakheten ved å ha med så mange forfattere mer påfallende. Man savner de store linjene, og flere skribenter tangerer de samme viktige spørsmålene, uten at man alltid går nok i dybde og bredde.

I et slikt verk ville man ha ventet å finne i første rekke en dokumentasjon på aktuelle, sosiale årsaker til psykisk og somatisk sykdom og dødelighet slik undertittelen signaliserer. Det forundrer meg derfor at de fleste forfatterne hamrer løs på de sosiale helseforskjellene i Norge og andre vestlige land. Har redaksjonen gitt alle medarbeiderne råd om en slik prioritering?

Dette er en viktig bok, og det er mye å lære her. Men den kan gjøres mer interessant og pedagogisk bedre. I neste utgave bør man etter mitt syn kutte ned på antall bidragsytere, begynne med et historisk sammendrag av utviklingen av sykdomsbildet gjennom de siste 100-150 årene, fortelle hvordan infeksjonssykdommene, ikke minst tuberkulosen, dominerte helt frem til annen verdenskrig med barn og unge som de hardest rammete, og hvordan dette endret seg etter siste verdenskrig med hjerte- og karlidelser, kreft og psykiske lidelser som sentrale helseplager med et helt annet aldersmønster, og hvordan man gjennom de siste 30 årene har fått en epidemi av uklare tilstander med diagnoser som fibromyalgi, whiplash og kronisk utmattelsessyndrom.

For å demonstrere betydningen av sosiale årsaker bør man så gripe fatt i hjerteinfarktepidemien som begynte i USA i 1940-årene og kulminerte der i slutten av 1960-årene, for så å tilta i Vest-Europa, der særlig Finland og Skottland hadde høye rater, med en senere økning i Øst-Europa.

Genene forandrer seg ikke på tusener av år. Bare sosiale årsaker kan gi en rimelig forklaring på oppgangen og nedgangen av de koronare hjertelidelsene de siste 60-70 årene. Medisinere har fremhevet røyking og fettrik kost som årsak til oppgangen, og reduksjon av røyking og mer mosjon som årsak til nedgangen - og selvsagt bedre behandling. Men dette er til dels tvilsomme hypoteser som en sosialmedisinsk lærebok burde ha diskutert.

Jeg savner også en oversikt over utbredelse og sosiale årsaker til psykiske lidelser. Schizofreni, bipolar lidelse og demenstilstander synes å ha holdt seg relativt konstante de siste 100 årene, mens lettere depresjoner, suicid, alkohol- og stoffproblemer har økt, ikke minst hos yngre mennesker.

La dette være noen velmente forslag fra en eldre herre som er opptatt av de store historiske linjene og det globale perspektivet. To skrifter gir en mer grundig argumentasjon for synspunktene $(1,2)$.

\section{Einar Kringlen}

Psykiatrisk institutt

Universitetet i Oslo

Litteratur

1. Kringlen E. Psychosocial aspects of coronary hear disease. Acta Psychiatr Scand 1986; 74: 225-37.

2. Kringlen E. Medisin og samfunn. 2. utg. Oslo: Universitetsforlaget, 1996.

\section{Råd for behandling av akutte sår}

Støren HJ.

Vurdering og behandling av akutte sår 143 s, ill. Oslo: Unipub, 2010. Pris NOK 298 ISBN 978-82-7477-456-8

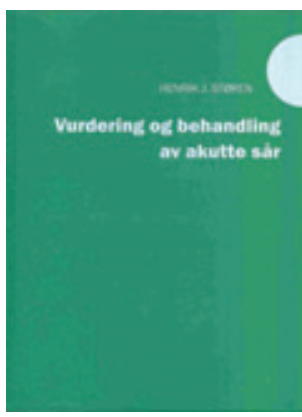

For mange som begynner i turnus, kan det være skummelt med den første vakten på skadepoliklinikken eller å være uerfaren legevakt i distriktet. Man er usikker på hva som kan komme, og noen ganger er

man usikker på hvor mye råd det er å hente i bakvakten. Da er det godt å ha noen som klarer å sette gode råd i system, slik som Henrik J. Støren har gjort i denne lommeutgaven om vurdering og behandling av akutte sår. 